\title{
A brief history of lumpfishing, assessment, and management across the North Atlantic
}

Kennedy, James; Durif, Caroline M. F.; Florin, Ann-Britt; Fréchet, Alain; Gauthier, Johanne; Hüssy, Karin; Jónsson, Sigurður Pór; Ólafsson, Halldór Gunnar; Post, Søren Lorenzen; Hedeholm, Rasmus B.

\section{Published in:}

ICES Journal of Marine Science

Link to article, DOI:

10.1093/icesjms/fsy146

Publication date:

2019

Document Version

Peer reviewed version

Link back to DTU Orbit

Citation (APA):

Kennedy, J., Durif, C. M. F., Florin, A-B., Fréchet, A., Gauthier, J., Hüssy, K., Jónsson, S. P., Ólafsson, H. G., Post, S. L., \& Hedeholm, R. B. (2019). A' brief history of lumpfishing, assessment, and management across the North Atlantic. ICES Journal of Marine Science, 76(1), 181-191. https://doi.org/10.1093/icesjms/fsy146

\section{General rights}

Copyright and moral rights for the publications made accessible in the public portal are retained by the authors and/or other copyright owners and it is a condition of accessing publications that users recognise and abide by the legal requirements associated with these rights.

- Users may download and print one copy of any publication from the public portal for the purpose of private study or research.

- You may not further distribute the material or use it for any profit-making activity or commercial gain

- You may freely distribute the URL identifying the publication in the public portal 


\section{A brief history of lumpfishing, assessment and management across the north Atlantic Ocean}

Kennedy, J. ${ }^{1,2}$, Durif, C.M.F. ${ }^{3}$, Florin, A. -B. ${ }^{4}$, Fréchet, A. ${ }^{5}$, Gauthier, J. ${ }^{5}$, Hüssy, K. ${ }^{6}$, Jónsson, S. P. ${ }^{1}$, Ólafsson, H. G. ${ }^{2}$, Post, S. $^{7}$ and Hedeholm, R. B. ${ }^{7}$

${ }^{1}$ Marine and Freshwater Research Institute, Skúlagata 4, PO Box 1390, Reykjavík 121, Iceland.

${ }^{2}$ Biopol, Einbúastíg 2, Skagaströnd, Iceland.

${ }^{3}$ Institute of Marine Research, Austevoll Research Station, 5392 Storebø, Norway.

${ }^{4}$ Institute of Coastal Research, Department of Aquatic Resources, Swedish University of Agricultural

Sciences, SE-742 42 Öregrund, Sweden.

${ }^{5}$ Fisheries and Oceans Canada, Maurice Lamontagne Institute, 850 route de la Mer, Mont-Joli, Quebec, Canada, G5H $3 \mathrm{Z} 4$

${ }^{6}$ National Institute of Aquatic Resources, Technical University of Denmark, Kemitorvet, Building 201, 2800 Kgs. Lyngby, Denmark.

${ }^{7}$ Greenland Institute of Natural Resources, Kivioq 2, P.O. Box 570, 3900 Nuuk, Greenland.

Keywords: lumpsucker, roe fishery, gillnets, marine stewardship council

\section{Abstract}

This report documents the fishery, assessment and management of lumpfish (Cyclopterus lumpus) across its distribution range. Targeting lumpfish for their roe on a large scale began in the 1950s in Iceland and Norway and then in Canada in the 1970's and Greenland in the 1990's. When the fishery began, there were few regulations but limits on vessel size, mesh size, number of nets and limits in the length of the fishing season were gradually implemented over time. Worldwide landings have varied from approximately 2000 to 8000 tonnes of roe between 1977 and 2016. Iceland and Canada accounted for $>80 \%$ of landings up until 2000. After 2013, Greenland and Iceland accounted for $>94 \%$. All countries except Iceland show a decreasing trend in the number of boats participating in the fishery which is related to several factors: the monetary value of the roe, changes in the abundance of lumpfish and increasing age of artisanal fishers. Each country has a different combination of data available for assessment, from basic landings and fishing effort data, to more detailed fishery independent survey indices of abundance. The management of total catch also differs with an effort-controlled fishery in Iceland, a total allowable catch (TAC) per boat in Norway and TAC per area in Greenland. Population abundance is above management targets in Iceland and Norway, but the status is less clear in Greenland and around Denmark/Sweden and appears to be depleted around Canada. Certification by the Marine Stewardship Council was instrumental in the adoption of a management plan in Greenland however benefits to the fishers remain unclear. Aspects surrounding the biology of lumpfish which are poorly understood and require investigation include growth rate, natural mortality and population differentiation. In addition, there is concern about the potential impacts the recent 
escalation in production of lumpfish for use as cleaner fish in the aquaculture industry could have on the wild population.

\subsection{Introduction}

During 2015 and 2016, experts on lumpfish from six countries (Canada, Greenland, Iceland, Norway, Sweden and Denmark) came together to form the lumpfish working group (LWG) to share knowledge on the biology, research, fishery assessment, and management of lumpfish (Cyclopterus lumpus) in their respective country. The group aimed to identify knowledge gaps which hinder the stock assessment of this species, where future research should be focussed and possible implications from the recent development of catching lumpfish as broodstock for the cleanerfish industry. Given the challenges of understanding this species, the LWG aimed to collate the information and data presented into a form which could easily be shared with interested parties. This resulted in the current manuscript which outlines how the fisheries are conducted and managed and describes the different methods used for assessment of the population in each country. Landings data from each country is brought together and standardised into a common format in order to get an overview of total landings.

The lumpfish (Figure 1), is a non-shoaling, coldwater marine fish in the family Cyclopteridae (lumpsuckers) and is the only member of the genus Cyclopterus. It is distributed across the northern Atlantic Ocean and is most abundant around the waters of Iceland, Norway, Greenland and Canada. It is also found in the North Sea and Baltic Sea and specimens have been caught in Galicia, Spain (Bañón et al., 2008), along the coast of Portugal (Vasconcelos et al., 2004) and Mediterranean Sea (Dulčić and Golani, 2006). Lumpfish is a semi-pelagic/semi-demersal species. Juveniles are thought to be mainly pelagic as they are frequently caught in pelagic nets but rarely in demersal trawls (Holst, 1993; Eriksen et al., 2014; ICES, 2016). However, upon reaching maturity and as spawning approaches, they begin their migration to coastal areas and display a mix of pelagic/demersal behaviour (Kennedy et al., 2016). The males generally arrive at the coast between January and March and the females several weeks later (Davenport, 1985). In Canada, the fish do not arrive at the coast until May. When the females arrive in coastal areas, they are the subject of a commercial fishery, primarily for their roe (Johannesson, 2006). The age at maturation and longevity for most regions is uncertain because age estimation based on otoliths has not been validated (Thorsteinsson, 1981; Albert et al., 2002). Initial estimates for Greenland put age at maturity at 3-4 years old, with the oldest fish examined being 5 years old which indicates that this species may exhibit a semelparous life strategy (Hedeholm et al., 2014).

The populations in the eastern and western Atlantic are genetically differentiated, which may be due to the polar water, which flows southward along the eastern Greenland coast, acting as a barrier to gene flow (Pampoulie et al., 2014; Garcia-Mayoral et al., 2016; Jonsdottir et al., 2018). There is genetic structuring of the lumpfish population in western Greenland with two major subpopulations, the northern and southern population. The northern population exhibits a greater similarity to the Canadian population than the geographically closer southern Greenland population (Garcia-Mayoral et al., 2016). The population of 
lumpfish in the northeast Atlantic exhibits a continuous distribution from the Irminger Sea off Southeast Greenland, up into the Denmark Strait and across the Norwegian Sea to Norway (ICES, 2016). There is no genetic differentiation within this population (Pampoulie et al., 2014; Garcia-Mayoral et al., 2016) and due to the continuous distribution between Iceland and Norway, it seems likely that there is some exchange of individuals between the Icelandic and Norwegian population. However, the degree of exchange (if any) is unknown and thus it is unclear if it has any significant implications for assessment or management. The lumpfish population within the Skagerrak, Kattegat and the Baltic is subject to a commercial fishery from both Denmark and Sweden, but the population structure within these areas is poorly understood.

An unusual characteristic of the lumpfish fishery is that it primarily targets the females and almost universally only the roe is landed. This makes it problematic for accurate estimation of landings as the weight of the roe needs to be converted into ungutted weight of the whole fish. Different countries employ different methods for the collection of landings data and for the conversion to ungutted weight. The methods for doing this may also have varied over time within a country. For this reason, comparison of landings between countries is difficult.

In addition to the fishery for the roe, a small fishery has recently developed in Norway, Iceland, Canada and also the United Kingdom (where no significant lumpfish fishery existed previously) which targets mature individuals to be used as broodstock to produce juvenile lumpfish. These juvenile lumpfish are used as cleaner fish to control sea lice infestation in salmon aquaculture.

The information below describes the fishery, how the population is assessed and how the fishery is managed in each country. Landings data from each country is collated in a common form (Figure 2) thus allowing a fair comparison of the total landings from the six countries considered (Figure 3 ).

\subsection{Fishery}

Four countries largely dominate the worldwide landings of lumpfish, Iceland, Norway, Greenland and Canada, there is also a small fishery in Denmark and Sweden (Figure 3). The fishery in Iceland and Norway began in the 1940-50s, during the 1970s in Canada and in the 1990s in Greenland. In all these countries, the fleet consists exclusively of small coastal vessels generally $<15 \mathrm{~m}$ in length which target the fish with large mesh bottom set gillnets. As lumpfish is targeted for their roe, and the carcass has little commercial value, the carcasses are disposed of at sea and only the roe is landed. This practice is almost universal across all the countries with the exception of a small amount of carcasses being landed in Greenland in recent years, while in Iceland, it became mandatory in 2012. In all countries except Iceland, the number of boats taking parts in the fishery has been declining, with a concurrent decline in landings (Figure 2).

The fishery is concentrated in specific areas in each country. In Iceland, this is primarily on the west and north coast, exclusively along the western coast of Greenland (from 60 to $70^{\circ} \mathrm{N}$ ) and mainly in the northern coast of Norway between Lofoten and the Varanger peninsula (Figure 4). In Canada, the fishery commenced off the northeast coast of Newfoundland (NAFO Divisions $3 \mathrm{~K}$ and $3 \mathrm{~L}$ ), spread to the south 
coast (Division 3P) and later to the west coast of Newfoundland, the coast of Labrador (Division 4R) and the lower north shore on the coast of Quebec (Division 4S) (Figure 4). Detailed information on lumpfish fishing areas for Sweden and Denmark is lacking.

The timing of the fishery varies between countries with the longest season in Iceland which typically lasts from March until August. Fishing usually takes place in April-May and April-June in Greenland and Norway respectively. In Canada, the fishing season is dependent on the melting of sea ice, but typically takes place in May-July. There is currently limited information on the timing of the fishing season in Sweden and Denmark.

In addition to the female roe fishery, there is also a small scale commercial fishery in Iceland for male lumpfish. Between 2 and 17 boats have participated in this fishery each year since 2002. These are fished with gillnets with a mesh size which must be between 178 and $203 \mathrm{~mm}$. Landings have varied from 30 to 70 tonnes per year between 2002-2016 and is primarily for the local market to be used as food. There are no restrictions on the total allowable catch (TAC) but it is illegal to fish using male lumpfish nets between 15 th June and 31st December. The majority of landings are from January to March, after which catches and prices decline.

A recent development in the salmon aquaculture industry has been the use of juvenile lumpfish as cleaner fish. The lifecycle has not been closed and production relies upon broodstock taken from the wild. The removals of wild fish is low in comparison with the roe fishery, $\sim 200$ fish in Iceland and $\sim 6.4$ tonnes of fish in Norway in 2017. However, a fishery for adult broodstock is also developing in countries where no lumpfish fishery previously existed i.e. United Kingdom and Ireland.

\subsection{Assessment}

The availability of data for assessment varies between countries (Table 1). To monitor changes in abundance, Iceland (Figure 5), Canada (Figure 6) and Sweden (Figure 7) utilise data from bottom trawl surveys, while Norway utilises data from a pelagic survey (Figure 5). As lumpfish is not routinely aged in any country, precluding the use of age structured populations models, and that the catchability of lumpfish in the trawl surveys is unknown, the survey indices are only a relative index of changes in populations biomass between years. While the survey index from Iceland and Norway are considered to give a reliable indication of changes in stock size (Eriksen et al., 2014; Kennedy and Jónsson, 2017), this has never been explicitly examined in Canada or Sweden. The Swedish survey catches an average of $<1 \mathrm{~kg}$ of lumpfish per hour of trawling which raises doubt about whether this reflects the abundance of lumpfish. In both Iceland and Norway, landings data and the stock index are used to calculate an index of relative fishing mortality $\left(\mathrm{F}_{\text {proxy }}\right)$ over time.

In Greenland, there are no surveys which can be used to give an estimate of population size. Thus assessment is entirely based upon landings data, which is used to give an index of Landings Per Unit Effort (LPUE) (Figure 8). In Canada, the population is assessed using a variety of indicators which include data from bottom trawl surveys, trends in landings and effort in the fishery and a fishery performance index 
which is essentially an aggregated CPUE index (total landings from fleet/number of fishing trips), In Sweden, the situation is similar with data from two ICES bottom trawl surveys from the North Sea and Baltic Sea and CPUE data from the fishery used to give an indication of population trends. In Denmark there is no formal assessment.

Based upon the stock assessment, the research institutions responsible for the assessment in Iceland, Greenland and Norway issue TAC advice for their respective population. In Greenland, the TAC, along with the number of fishing days, is set according to the harvest control rule (Figure 9). In Iceland, the goal of the advice is to maintain $\mathrm{F}_{\text {proxy }}$ below the average value from the reference period (1985-2011). This was initially estimated at 0.75 , but after revision of historical landings this is now 0.66 but the initial value continues to be used. Thus, the TAC corresponds with a value that would lead to a $\mathrm{F}_{\text {proxy }}$ of 0.75 . The Norwegian advice is based upon trend analysis of survey data but there are no defined reference points. The aim of the advice is to keep the harvest rate around $1 \%$ of the biomass index. No TAC advice is given for the fishery in Canada, Denmark or Sweden.

\subsection{Management}

The degree of management of the lumpfish is substantially different between each country with each country employing a unique range of management measures (Table 2) which have evolved over time (Table 3). The fishery in Denmark is essentially unmanaged with no regulations specific to the targeting of lumpfish, while in Sweden, only the mesh size when targeting lumpfish is regulated. In Canada, the fishery has been managed through effort controls since 1992. These measures are minimal but include a limit of 50 gillnets of $91 \mathrm{~m}$ (50 fathoms) with a minimum mesh size of $267 \mathrm{~mm}$ and a time limit on the duration of the season.

The lumpfish fishery in Greenland was unregulated prior to 2015 when a management plan was adopted in connection with Marine Stewardship Certification (MSC) certification (MSC, 2014). This involved the introduction of a TAC (initially set at 1500 tonnes of roe, the average landings between 2010 and 2013) and a maximum number of fishing days. This quota is divided between seven management areas (six NAFO management areas with area 1B split in two (Figure 4)) with the local buyers of roe deciding when to start the fishery. The fishery proceeds until either the quota for the management area is exhausted or when the designated number of fishing days has passed. The majority of the commercial fleet is not obligated to fill out logbooks as most vessels are exempt due to their size (below $9 \mathrm{~m}$ ).

The fishery has been regulated in Norway since 1988 but only in the three most northern counties: Nordland, Troms, and Finmark. Anyone can participate in the fishery if their boat is below $13 \mathrm{~m}$. The fishery is regulated through a TAC per boat, which was initially set at 6.5 tonnes of roe. The initial minimum mesh size was set to $252 \mathrm{~mm}$ and was increased in 1999 to $267 \mathrm{~mm}$. Since 2006, fishing is limited to the period before June 20th (July 5th for East Finmark).

The Icelandic fishery is managed using input controls with limited entry, limited fishing period, maximum number of consecutive fishing days for each boat, maximum length of nets and maximum size of 
boat. In 1991, the number of boats which could participate in the fishery was effectively capped, as only boats which had fished for one year in the previous four could participate in the fishery. A similar rule was implemented in 1996 and all boats which were eligible to participate in the fishery were assigned a lumpfish permit, which is required to participate in the fishery. The permits are transferrable between boats, no new permits are issued and a permit can be lost if a boat is scrapped and the licence is not transferred to a new boat within a specified period. To utilise a permit in any particular year, the boat owner must notify the Directorate of Fisheries before commencing fishing and select one of seven management areas (Figure 4) for their fishing operations for that year. At the time of writing (May 2018), 449 boats had a permit to fish lumpfish (www.fiskistofa.is).

In 2005, following a request from the National Association of Small Boat Owners (NASBO) due to falling prices for lumpfish roe, the government introduced a limit on the maximum number of consecutive days each boat could fish. The allocated days could be used at any time within the fishing season of their chosen area. In 2012, MFRI, began offering advice on TAC for lumpfish. This is now taken into consideration alongside input from NASBO when the maximum number of fishing days for fishing is decided. Since 2005, the number of consecutive days fishing has varied from 32 to 62 days.

\subsection{Discussion}

The current status of lumpfish populations spans the whole range from healthy and fairly certain to depleted and unknown. The populations in Iceland and Norway have increased following low population biomass in the 1990s and are above the long term average. It appears that the lumpfish population in Canada is depleted. Due to the short time series, there is less certainty about the population status in Greenland and the population status in the Baltic Sea and Kattegat is unknown due to lack of reliable data.

Participation in lumpfish fisheries have been declining in all but one country (Iceland). Anecdotal information suggests the declining price of roe, both in real terms and in relative terms in regard to the price of other species such as Atlantic cod (Gadus morhua) and Greenland halibut (Reinhardtius

hippoglossoides), is the primary reason. Other factors such as status of the lumpfish population can also play a role; with a low population biomass, catches are low so targeting lumpfish can be unprofitable which might be the case in Canada.

As the lumpfish fishery is seasonal, the ability to easily move to other fisheries during other parts of the year is an essential component for participation. For established fishers, the decision to take part in the fishery does not require a substantial long-term investment, but only a small investment in gillnets which are typically replaced after 1 to 2 years. This flexibility means that participation can rebound quickly as was seen in Iceland between 2007 and 2011 when the number of boats taking part increased 2.5 times (Marine Research Institute (Iceland), unpublished data). Social changes may also play a role which is thought to be the case in Denmark and Sweden, with a decline in number and increase in the average age of subsidiary fishers which went from 1069 fishers with an average of 59.1 years to 972 fishers with an average age of 
64.1 years between 2007 and 2016 (http://webfd.fd.dk/stat/aldersstatistik/bierhvervsfiskere_eng2016.html, accessed June 2018).

Strong management and regular assessment of stock status is the key to a sustainably managed species (Hilborn and Ovando, 2014; Melnychuk et al., 2016; Pons et al., 2016). The case of the lumpfish population in Canada strongly emphasises this point, with limited management restrictions, a lack of data on the fishery and few assessments. This highlights the need for lumpfish populations to be regularly assessed coupled with responsive management measures in place to prevent long term overfishing. This is however not the case for Sweden or Denmark where there is only limited assessment of the population with few meaningful restrictions on the fishery. As Denmark and Sweden are very likely targeting the same population greater collaboration to pool assessment and fishery data and to produce a combined management plan for this species would be advisable.

A major hindrance in the stock assessment of lumpfish is the difficulty in interpreting the otoliths for estimating the age of the fish. In addition, the ageing technique that is currently in use has not been validated (Albert et al., 2002; Hedeholm et al., 2014). Ageing of lumpfish in Greenland suggests that the majority of the spawning population comprises 3 and 4 year old fish. This suggests that post-spawning survival is low and that lumpfish exhibit a semelparous life strategy (Hedeholm et al., 2014, Kasper et al., 2014). An alternative explanation is that growth is very low after spawning making, it difficult to distinguish growth rings on the outer edge of otoliths of older age classes. In Iceland, as the population declined between the 1980's and 1990's, there was a concurrent truncation in the length distribution (Kennedy and Jónsson, 2017). A change in length distribution is not an expected response for a semelparous species undergoing a population decline. These differences may reflect a difference in life history between populations. In order to resolve this issue, further studies are needed and age validation should be a high priority in future lumpfish research.

There are also several issues which hinder the assessment of specific stocks. The location and distribution of juveniles and mature fish outside the breeding season (if assuming an iteroparous life history) from the Greenland and Canadian population is unknown. Such knowledge could allow for an estimation of abundance of pre-recruits, as management, in the case of Greenland, is currently based upon stock assessments from the previous year. This is even more relevant if lumpfish do have a high degree of semelparity. It could also allow an evaluation of stock structure along the coast of Greenland.

Each country has its own unique combination of management measures, some of which have been in place for several decades. The majority of these management measures were not intended to limit catches to a specific level as the populations were not formally assessed. However, population assessment and management measures have been slow to appear with catch limits not being introduced in Norway until 1988 and it was not until 2012 that MFRI in Iceland began to offer TAC advice. In contrast, the formulation of a management plan in Greenland in 2015 was fairly quick in comparison as the fishery did not begin until the late 1990s. 
As the different management measures have been in place during a short period, and during a time of low participation in the fishery, it is difficult to compare their effectiveness. However, there are some obvious flaws in several of these approaches. Both Iceland and Canada employ effort restrictions as their main method of limiting catches. Both countries have limits on the number of nets and number of fishing days. In addition, Iceland also has a cap on the number of boats which can participate in the fishery. However, the number of fishing days for the season is decided before the number of boats which will participate in the fishery is known. This makes it very difficult to precisely control total effort in the fishery and thus limits the effectiveness of this approach. While Norway and Greenland employ a TAC system, the Norwegian system sets a TAC for each boat. However there is no limit on the number of boats which can participate in the fishery. In Norway, if participation in the fishery were to rise, the current management approach could make it difficult to limit catches within a particular year. However, if the rise in boat numbers was gradual over several years and provided there are no major fluctuations in boat numbers from year to year, TAC per boat can be adjusted to compensate for this increase in boat numbers. The disadvantages of such a system is that there can be an under utilization of the TAC, if fewer boats than expected participate in the fishery. Greenland is the only country to employ a fisheries wide TAC, however there is no allocation of quota to individual boats. The lack of individual quotas can result in a 'race to fish' scenario, which has several disadvantages (Branch et al., 2006). As the fishing season is constrained by the biology of the species i.e. the spawning period, there is little possibility to extend the fishing season. Thus the benefits of an individual transferable quota (ITQ) system (Grafton, 1996) may not be realised. Lastly, given that the population is monitored using LPUE from fisheries data, there is the possibility that an overall population decline may be masked due to fish remaining equally abundant in 'hot spots' thus a fishery independent indicator should ideally be considered.

The MSC certification has played an interesting role in the assessment and management of the lumpfish fishery. The advice issued by the MFRI (Iceland) was met with resistance from the fishers (Bogason, 2014), however, when the fishery was MSC certified, this situation improved. Following the MSC certification in Iceland, Greenland also sought certification and the management plan in Greenland was a direct result of the MSC assessment. Without a management plan in place, it seems unlikely that MSC certification would have been achieved. There has been no specific investigation into the effect of the MSC certification on the price received by the fishers; anecdotal information suggests that the price did not increase, which reflects the situation which followed the MSC certification of Atlantic cod in Sweden (Blomquist et al. 2015). The decreasing participation in the Greenland fishery suggests the achievement of MSC certification has not been sufficient to maintain interest in the lumpfish fishery; note that the alternative fishing opportunities (coastal fishing for Atlantic cod and Greenland halibut) are not MSC certified. While the MSC certification was instrumental in implementing management of lumpfish, the benefits for the fishers themselves are currently unclear. The lumpfish fishery in Norway was recently MSC certified (MSC, 2017a), whether this will rekindle interest in this fishery remains to be seen. 
Due to the removal of roe at sea, the total weight of ungutted lumpfish has to be estimated based upon the amount of roe present in the ovary. The current official conversion factors utilised by Norway and Greenland (6.7 for fresh roe) are unrealistic and greatly overestimates total catch. Estimates from fish sampled from the fishery in Greenland put the gonad weight at an average of $27 \%$ of the total weight of the fish which equates to a conversion factor of 3.7 (Hedeholm et al., 2014). A similar value (30.5\%, a conversion factor of 3.28) was estimated for lumpfish in Iceland using logbook data (Kennedy and Jónsson, 2017). In Canada, two studies also concluded that during fishing season, the female lumpfish gonad represented, on average, $28 \%$ of the fish total weight (Stevenson and Baird, 1988; Gauthier et al., 2016). If landings data are consistently reported as weight of roe, then the actual conversion factor is not vastly important as the data can still be used to assess relative change in the amount of lumpfish caught over time. However, inaccurate conversion factors create problems when comparing catches between countries. For example, Powell et al. (2018) attributes c. 70\% of the world catch of lumpfish to Greenland, a more accurate estimate would be $20-40 \%$. Problems can also arise if the method for collecting landings data changes as it did in Iceland where landings are almost exclusively ungutted lumpfish. In this case, to ensure the comparability between historical and present landings, an accurate estimation of the amount of roe is essential.

The large mesh size of lumpfish nets is highly selective for lumpfish with very low levels of fish bycatch. Fish which are caught are of marketable size and thus there is little concern in regards to the capture and discarding of juvenile fish. Lumpfish can survive for several days when caught in the net (Kennedy et al., 2016) thus lumpfish nets may be left in the water for several days. This extended soak time can lead to discarding of non-target species due to the deterioration in quality of the fish. There is currently no data available on discarding of non-target species in lumpfish fisheries, but this should be evaluated as this represents an unaccounted source of fishing mortality for the species in question.

Bycatch of non-fish species is of significant concern in many fisheries. The use of gillnets in shallow water in coastal areas presents significant risks for coastal seal species and diving birds (Žydelis et al., 2013). This is of significant concern both in Iceland and Norway. Due to a lack of data on the exact levels of bycatch, it is difficult to estimate the risk lumpfish fisheries pose to bird populations. With Iceland, Norway and Greenland all receiving MSC certification (note that Iceland's certification was suspended in 2018 due to issues of bycatch (MSC, 2017b)), these fisheries must increase effort in collecting data on bycatch of marine mammals and birds. For this to happen and to find solutions to any bycatch issues which may become apparent, active engagement from managers, research institutions and the fishers themselves is required.

There is currently intense focus on the development and use of lumpfish in the fight against sea lice in the salmon aquaculture industry (Imsland et al., 2014). The production and sale of lumpfish has risen rapidly in the last few years; in Norway, the number of cultured lumpfish sold to the aquaculture industry increased from 431 thousand to 13.4 million fish between 2012 and 2015 (http://www.fiskeridir.no). This rapid rise in production raises concerns about potential impact of escapees on their wild counterparts 
(Powell et al., 2017) which is a major concern in other species e.g. Atlantic salmon (Salmo salar) (Jonsson and Jonsson, 2006).

\section{Acknowledgements}

This study was funded by Working Group for Fisheries (AG-Fisk) from the Nordic Council of Ministers (project no. (123)-2014-Lumpfish wg), the Marine and Freshwater Institute (Iceland), Biopol (Iceland), Institute of Marine Research (Norway), Swedish University of Agricultural Sciences, Fisheries and Oceans Canada, Technical University of Denmark and Greenland Institute of Natural Resources. The authors would like to thank Niels Daan who provided the data for lumpfish from IBTS and BITS survey. Thanks to Mark Simpson, DFO Newfoundland, Canada who provided the Newfoundland survey data for lumpfish and two anonymous reviewers who provided helpful comments on an earlier version of the manuscript.

\section{References}

Albert, O. T., Torstensen, E., Bertelsen, B., Jonsson, S. T., Pettersen, I. H., and Holst, J. C. 2002. Agereading of lumpsucker (Cyclopterus lumpus) otoliths: dissection, interpretation and comparison with length frequencies. Fisheries Research, 55: 239-252. Elsevier.

Bañón, R., Garazo, A., and Fernández, A. 2008. Note about the presence of the lumpsucker Cyclopterus lumpus (Teleostei, Cyclopteridae) in Galician waters (NW Spain). Journal of Applied Ichthyology, 24: 108-109.

Blomquist, J., Bartolino, V., \& Waldo, S. 2015. Price Premiums for Providing Eco-labelled Seafood : Evidence from MSC-certified Cod in Sweden. Journal of Agricultural Economics, 66: 690-704.

Bogason, A. 2014. Vísindi eða villuljós? Brimfaxi -Tímarit landsambands smábátaeigenda, 1, 201428 -37. (in Icelandic)

Branch, T. A., Hilborn, R., Haynie, A. C., Fay, G., Flynn, L., Griffiths, J., Marshall, K. N., Randall, J. K, Scheuerell, J. M., Ward, E. J. and Young, M. 2006. Fleet dynamics and fishermen behavior: lessons for fisheries managers. Canadian Journal of Fisheries and Aquatic Sciences, 63: 1647-1668.

Dulčić, J., and Golani, D. 2006. First record of Cyclopterus lumpus L., 1758 (Osteichthyes: Cyclopteridae) in the Mediterranean Sea. Journal of Fish Biology, 69: 300-303.

Eriksen, E., Durif, C. M. F., and Prozorkevich, D. 2014. Lumpfish (Cyclopterus lumpus) in the Barents Sea: development of biomass and abundance indices, and spatial distribution. ICES Journal of Marine Science, 71: 2398-2402.

Garcia-Mayoral, E., Olsen, M., Hedeholm, R., Post, S., Nielsen, E. E., and Bekkevold, D. 2016. Genetic structure of West Greenland populations of lumpfish Cyclopterus lumpus. Journal of Fish Biology, 89: $2625-2642$.

Gauthier, J., Grégoire, F., and Nozères, C. 2017. Assessment of Lumpfish (Cyclopterus lumpus) in the Gulf of St. Lawrence (3Pn, 4RS) in 2015. DFO Can. Sci. Advis. Sec. Res. Doc. 2017/051. v + 47 p. 
Grafton, R. Q. 1996. Individual transferable quotas: theory and practice. Reviews in Fish Biology and Fisheries, 6: 5-20.

Hedeholm, R., Blicher, M. E., and Grønkjær, P. 2014. First estimates of age and production of lumpsucker (Cyclopterus lumpus) in Greenland. Fisheries Research, 149: 1-4.

Hilborn, R., and Ovando, D. 2014. Reflections on the success of traditional fisheries management. ICES Journal of Marine Science, 71: 1040-1046.

Holst, J. C. 1993. Observations on the distribution of lumpsucker (Cyclopterus lumpus, L.) in the Norwegian Sea. Fisheries research, 17: 369-372.

ICES. 2016. First Interim Report of the Working Group of International Pelagic Surveys (WGIPS), 18-22 January 2016, Dublin, Ireland. ICES CM 2016/SSGIEOM:05. 439 pp.

Imsland, A. K., Reynolds, P., Eliassen, G., Hangstad, T. A., Foss, A., Vikingstad, E., and Elvegård, T. A. 2014. The use of lumpfish (Cyclopterus lumpus L.) to control sea lice (Lepeophtheirus salmonis Krøyer) infestations in intensively farmed Atlantic salmon (Salmo salar L.). Aquaculture, 424-425: $18-23$.

Johannesson, J. 2006. Lumpfish cavier - from vessel to consumer. FAO Fisheries Technical Paper, 485: 71.

Jonsdottir, O.D.B., Schregel, J., Hagen, S.B., Tobiassen, C., Aarnes, S.G., and Imsland, A.K.D. 2018. Population genetic structure of lumpfish along the Norwegian coast: aquaculture implications. Aquaculture International, 26: 49-60.

Jonsson, B., and Jonsson, N. 2006. Cultured Atlantic salmon in nature: a review of their ecology and interaction with wild fish. ICES Journal of Marine Science, 63: 1162-1181.

Kasper, J. M., Bertelsen, B., Ólafsson, H. G., Holst, J. C., Sturlaugsson, J., and Jónsson, S. P. 2014. Observations of growth and postspawning survival of lumpfish Cyclopterus lumpus from markrecapture studies. Journal of Fish Biology, 84: 1958-1963.

Kennedy, J. and Jónsson, S. P. 2017. Do biomass indices from Icelandic groundfish surveys reflect changes in the population of female lumpfish (Cyclopterus lumpus)? Fisheries Research

Kennedy, J., Jónsson, S. P., Ólafsson, H. G., and Kasper, J. M. 2016. Observations of vertical movements and depth distribution of migrating female lumpfish (Cyclopterus lumpus) in Iceland from data storage tags and trawl surveys. ICES Journal of Marine Science, 73: 1160-1169.

Melnychuk, M. C., Peterson, E., Elliott, M., and Hilborn, R. 2016. Fisheries management impacts on target species status. Proceedings of the National Academy of Sciences: 201609915.

MSC 2014 Final Report - Initial assessment of the Greenland lumpfish fishery. Available at https://fisheries.msc.org/en/fisheries/greenland-lumpfish

MSC 2017a. Final Report: NFA Norwegian Ling \& Tusk and NFA Norwegian Lumpfish Fishery. Available at https://fisheries.msc.org/en/fisheries/nfa-norwegian-ling-tusk-and-nfa-norwegian-lumpfish

MSC 2017b. Icelandic Gillnet Lumpfish Third Annual Surveillance Report. Available at https://fisheries.msc.org/en/fisheries/icelandic-gillnet-lumpfish

Pons, M., Branch, T. A., Melnychuk, M. C., Jensen, O. P., Brodziak, J., Fromentin, J. M., Harley, S. J., Haynie, A. C., Kell, L. T., Maunder, M. N., Parma, A. M., Restrepo, V. R., Sharma, R., Ahrens, R. and 
Hilborn, R. 2016. Effects of biological, economic and management factors on tuna and billfish stock status. Fish and Fisheries: 1-21.

Powell, A., Pooley, C., Scolamacchia, M., and Garcia de Leaniz, C. 2018. Review of Lumpfish Biology. In Cleaner fish biology and aquaculture applications, pp.90-113. Ed. by J. Treasurer. $5 \mathrm{~m}$ publishing, Sheffield. 515 pp.

Powell, A., Treasurer, J. W., Pooley, C. L., Keay, A. J., Lloyd, R., Imsland, A. K., \& Garcia de Leaniz, C. 2017. Use of lumpfish for sea-lice control in salmon farming: Challenges and opportunities. Reviews in Aquaculture, 1-20. https://doi.org/10.1111/raq.12194

Pampoulie, C., Skirnisdottir, S., Olafsdottir, G., Helyar, S. J., Thorsteinsson, V., Jonsson, S. T., Fréchet, A., Durif, C. M. F., Sherman, S., Lampart-Ka uzniacka, M., Hedeholm, R., Olafsson, H., Danielsdottir, A. K., and Kasper, J. M. 2014. Genetic structure of the lumpfish Cyclopterus lumpus across the North Atlantic. ICES Journal of Marine Science, 71: 2390-2397.

Stevenson, S. C., Baird, J. W. 1988. The Fishery for Lumpfish (Cyclopterus lumpus) in Newfoundland Waters. Canadian Technical Report of Fisheries and Aquatic Sciences, 1595: 1-26.

Thorsteinsson, V. 1981. The ageing validation of the lumpsucker (Cyclopterus lumpus) and the age composition of the lumpsucker in Icelandic lumpsucker fisheries. ICES C.M., G58: 12 pp.

Vasconcelos, P., Monteiro, C. C., Santos, M. N., and Gaspar, M. B. 2004. First record of the lumpfish (Cyclopterus lumpus Linnaeus, 1758) off the Algarve coast (southern Portugal): Southward extension of the species distributional range. Journal of Applied Ichthyology, 20: 159-160.

Žydelis, R., Small, C., \& French, G. 2013. The incidental catch of seabirds in gillnet fisheries: A global review. Biological Conservation, 162, 76-88. 
Table 1. Summary of information regarding assessment and management in each country.

\begin{tabular}{|c|c|c|c|c|c|c|}
\hline Country & $\begin{array}{l}\text { Frequency } \\
\text { of } \\
\text { assessment }\end{array}$ & $\begin{array}{l}\text { Fishery independent } \\
\text { population index }\end{array}$ & $\begin{array}{l}\text { Is CPUE } \\
\text { data } \\
\text { available? }\end{array}$ & $\begin{array}{l}\text { Routine collection of } \\
\text { additional data }\end{array}$ & Management plan & $\begin{array}{l}\text { MSC } \\
\text { certification }\end{array}$ \\
\hline Iceland & Annual & $\begin{array}{l}\text { Relative biomass index } \\
\text { from demersal survey. }\end{array}$ & Yes & $\begin{array}{l}\text { Length-weight data } \\
\text { collected from landings. }\end{array}$ & $\begin{array}{l}\text { No formally adopted plan but aim of advice is } \\
\text { to maintain } F_{\text {proxy }} \text { below average of reference } \\
\text { period and maintain biomass above historical } \\
\text { minimum. }\end{array}$ & $\begin{array}{l}2015 \\
\text { Suspended } 2018\end{array}$ \\
\hline Greenland & Annual & None & Yes & No & Harvest control rule & 2016 \\
\hline Norway & Annual & $\begin{array}{l}\text { Relative biomass index } \\
\text { from pelagic survey. }\end{array}$ & Yes & No & None & 2018 \\
\hline Canada & Irregular & $\begin{array}{l}\text { Relative biomass index } \\
\text { from demersal survey. }\end{array}$ & Yes & No & None & No \\
\hline Sweden & Annual & $\begin{array}{l}\text { Relative biomass index } \\
\text { from demersal survey. }\end{array}$ & Yes & No & None & No \\
\hline Denmark & None & $\begin{array}{l}\text { Relative biomass index } \\
\text { from demersal survey. }\end{array}$ & No & No & None & No \\
\hline
\end{tabular}


Table 2. Summary of management regulations in each country.

\begin{tabular}{|c|c|c|c|c|c|}
\hline Country & Regulations for participation & Input controls & TAC & $\begin{array}{l}\text { Min-max mesh size } \\
(\mathbf{m m})\end{array}$ & Logbooks \\
\hline Iceland & $\begin{array}{l}\text { Boats require a lumpfish licence of which there are a limited } \\
\text { number. } \\
\text { Boat must be under } 15 \mathrm{GT} \text {. }\end{array}$ & $\begin{array}{l}\text { Limited entry. } \\
\text { Length of fishing period. } \\
\text { Area management. } \\
\text { Total length of nets. }\end{array}$ & No & $267-292$ & Yes \\
\hline Greenland & $\begin{array}{l}\text { Commercial fishing licence required for commercial } \\
\text { operations. No licence for non-commercial fishing }\end{array}$ & $\begin{array}{l}\text { Length of fishing period. } \\
\text { Area management. }\end{array}$ & Yes & Not regulated & $\begin{array}{l}\text { Only boats } \\
>9 \mathrm{~m} \text {. }\end{array}$ \\
\hline Norway & Boat must be under $13 \mathrm{~m}$. & $\begin{array}{l}\text { Length of fishing period. } \\
\text { Area management. }\end{array}$ & TAC per boat & 267-no max & Yes \\
\hline Canada & Must be a registered commercial fisher. & Total number of nets. & No & 267-no max & Yes \\
\hline Sweden & $\begin{array}{l}\text { Commercial fishing licence required for commercial } \\
\text { operations. No licence required for non-commercial fishing }\end{array}$ & None & No & $\begin{array}{l}\text { 120-no max (200 within } \\
\text { Kattegatt and The } \\
\text { Sound between } 1^{\text {st } J a n ~} \\
31^{\text {st }} \text { March. }\end{array}$ & Yes \\
\hline Denmark & $\begin{array}{l}\text { Commercial fishing licence required for commercial } \\
\text { operations. No licence required for non-commercial fishing }\end{array}$ & None & No & None & No \\
\hline
\end{tabular}


Table 3. Timeline of introduction of significant management measures.

\begin{tabular}{|c|c|c|}
\hline Year & Country & Management measure \\
\hline 1976 & Iceland & Boat size limited to 8 GRT and fishers must submit logbooks. \\
\hline 1977 & Iceland & $\begin{array}{l}\text { Maximum boat size increased to } 12 \text { GRT. The coast is divided into four areas, with } \\
\text { season limits for each area. } \\
\text { Limits are placed on the number of nets, } 40 \text { per fisher, never more than } 150 \text { per boat. } \\
\text { Introduction of a minimum mesh size of } 267 \mathrm{~mm} \text {. }\end{array}$ \\
\hline 1978 & Iceland & Licensing system introduced. \\
\hline 1988 & Norway & Introduction of a limit on the number of boats and TAC (6500 litres) per boat. \\
\hline 1991 & Iceland & $\begin{array}{l}\text { Only boats which participated in the fishery for at least one year between } 1987 \text { and } 1990 \\
\text { may participate. }\end{array}$ \\
\hline 1992 & Canada & $\begin{array}{l}\text { Introduction of a limit of } 50 \text { gillnets of } 91 \mathrm{~m} \text { ( } 50 \text { fathoms }) \text { with a minimum mesh size of } \\
267 \mathrm{~mm} \text { and a time limit on the length of the season. }\end{array}$ \\
\hline 1994 & Iceland & $\begin{array}{l}\text { Number of nets increased to } 100 \text { per fisher with a maximum of } 300 \text { per boat. } \\
\text { Breiðifjörður (area B) split into two areas to reduce bycatch of eider ducks. }\end{array}$ \\
\hline 1996 & Iceland & $\begin{array}{l}\text { Only boats which participated in the fishery for at least one year between } 1991 \text { and } 1994 \\
\text { may participate. }\end{array}$ \\
\hline \multirow[t]{2}{*}{1998} & Iceland & Only boats which could participate in the fishery in 1997 can participate. \\
\hline & Norway & A size limit $(13 \mathrm{~m})$ is placed on vessels which can participate in the fishery. \\
\hline 1999 & Norway & Minimum mesh size increased from $252 \mathrm{~mm}$ to $267 \mathrm{~mm}$. \\
\hline 2005 & Iceland & $\begin{array}{l}\text { Limitations on days at sea introduced by National Association of small boat owners for } \\
\text { economic reasons. }\end{array}$ \\
\hline 2006 & Norway & Fishing is restricted to the period before June 20th (July 5th for east Finmark). \\
\hline 2008 & Iceland & Directorate of Fisheries begins collecting landings data. \\
\hline 2012 & Iceland & MRI offers first TAC advice. It becomes mandatory to land bodies. \\
\hline 2013 & Iceland & $\begin{array}{l}\text { Number of nets reduced from } 100 \text { per crew member (max } 300) \text { to max } 200 \text { per boat. } \\
\text { Maximum soak time reduced from } 6 \text { to } 4 \text { days. }\end{array}$ \\
\hline 2014 & Iceland & Fishery received MSC certification. \\
\hline \multirow[t]{2}{*}{2015} & Iceland & Maximum number of nets replaced by maximum length. \\
\hline & Greenland & $\begin{array}{l}\text { Greenland management plan implemented. } \\
\text { Fishery received MSC certification }\end{array}$ \\
\hline 2016 & Greenland & Introduction of specific lumpfish license. \\
\hline 2017 & Norway & Fishery received MSC certification. \\
\hline 2017 & Canada & $\begin{array}{l}\text { Lumpfish fishery assessed by Committee on the Status of Endangered Wildlife in } \\
\text { Canada. }\end{array}$ \\
\hline 2018 & Iceland & MSC certification suspended \\
\hline
\end{tabular}




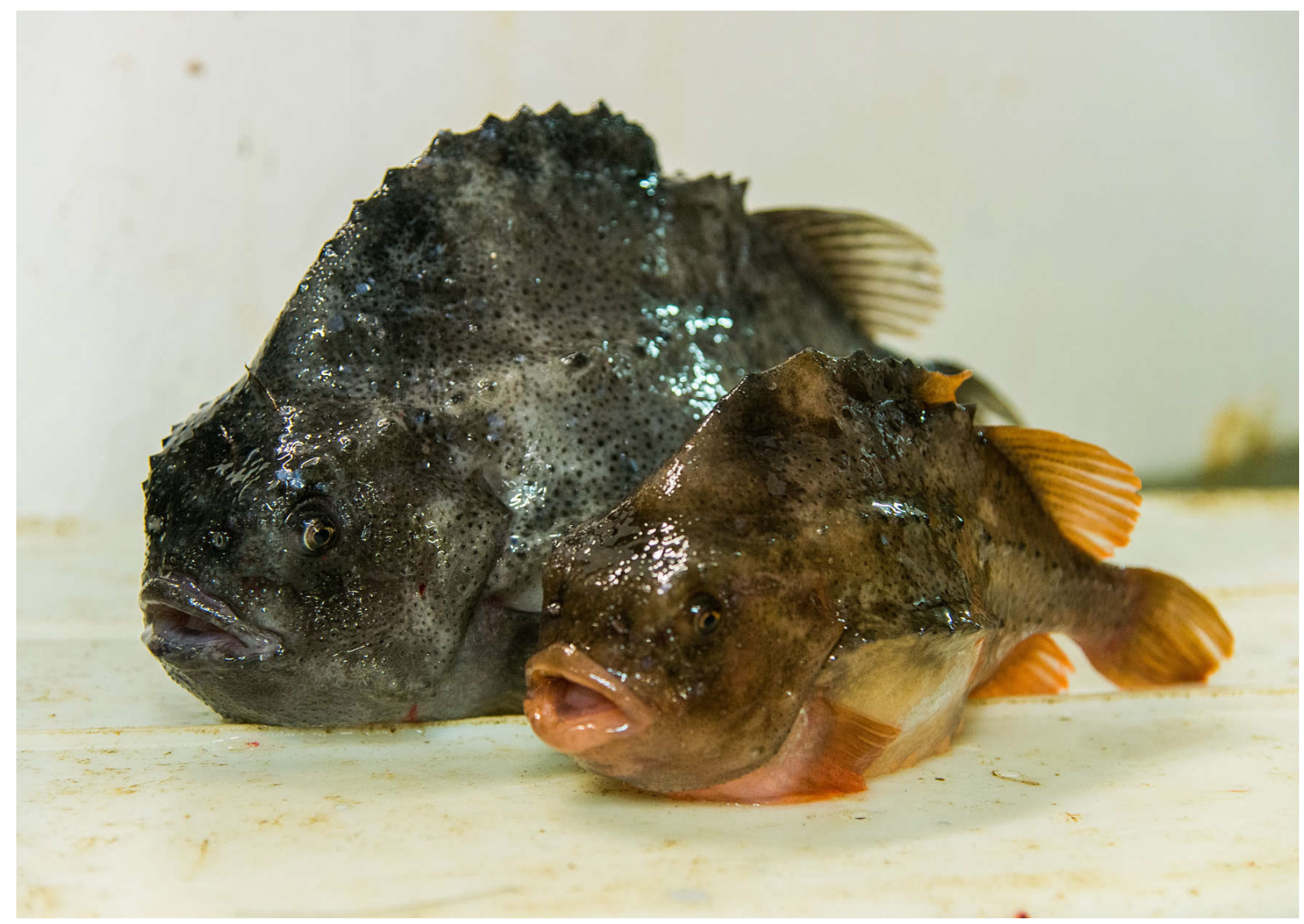

Figure 1 Male (foreground) and female (background) lumpfish. 

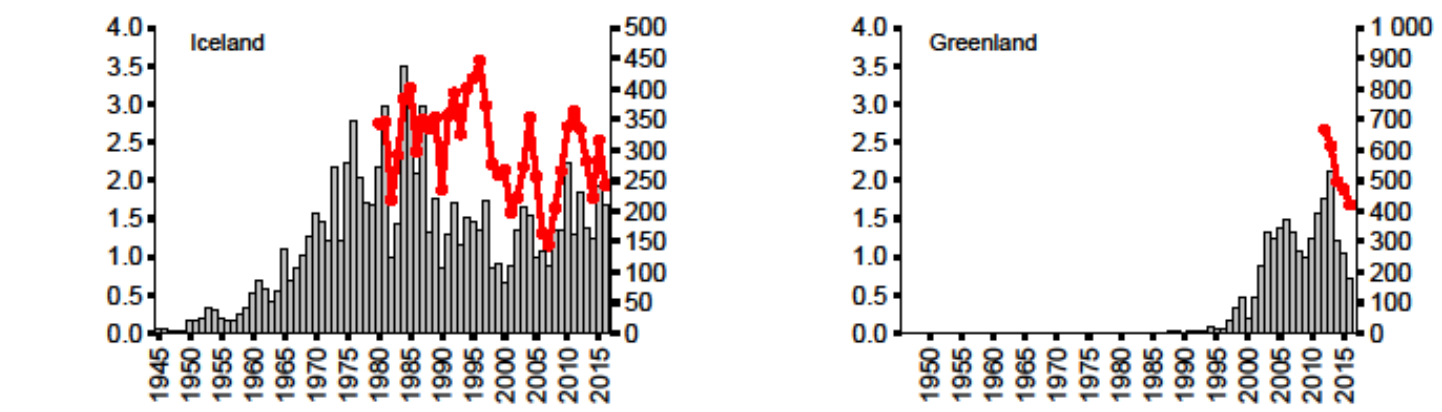

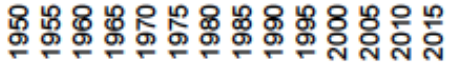
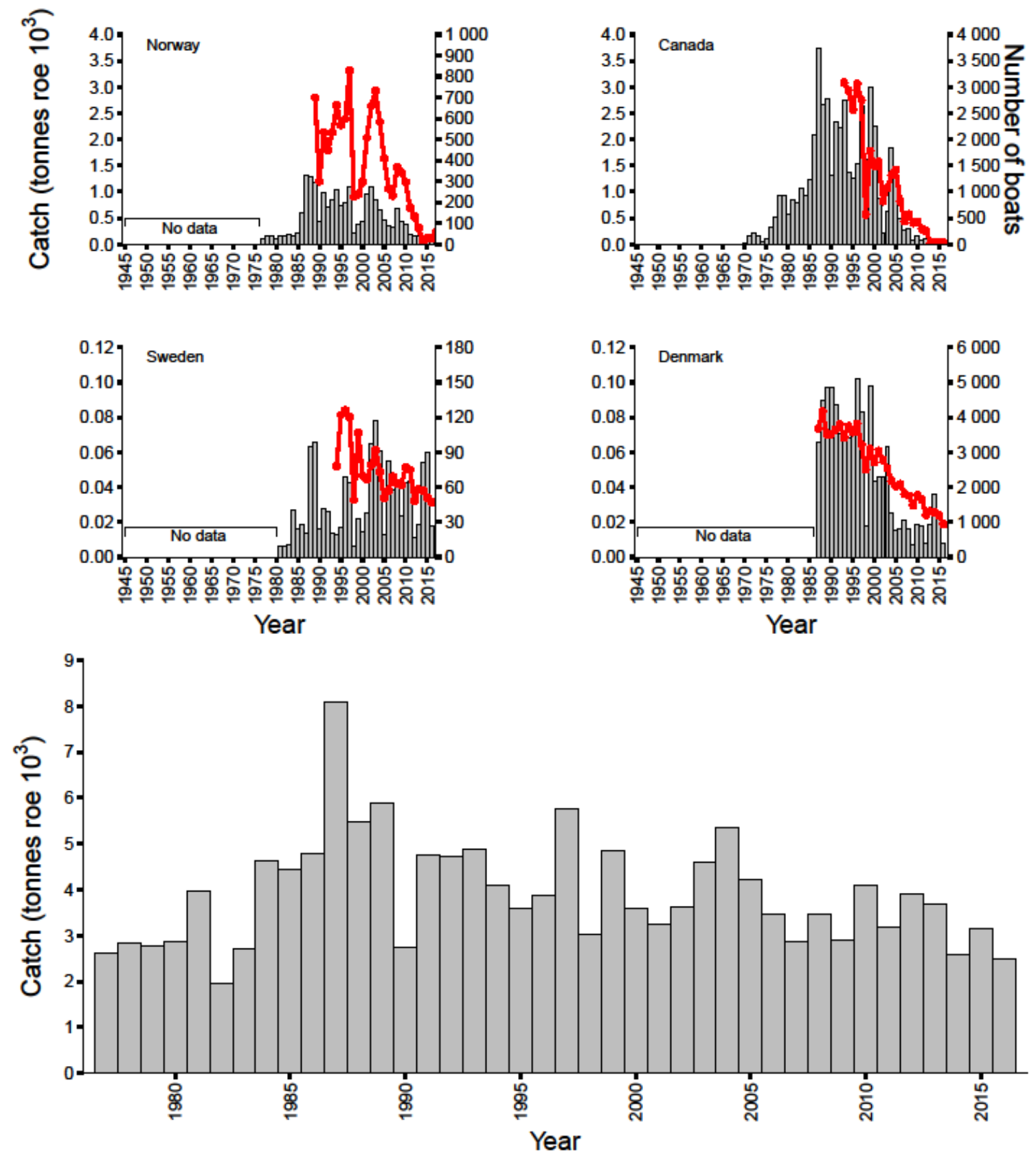

Figure 2. Landings of lumpfish roe (grey bars) and number of boats which participated in the fishery (red line) in each country and total landings from all countries combined (bottom graph). Areas labelled no data indicate that lumpfish was landed but data was not collected. Note differing left y-axis scale for Sweden and Denmark and differing right-y-axis between graphs. 


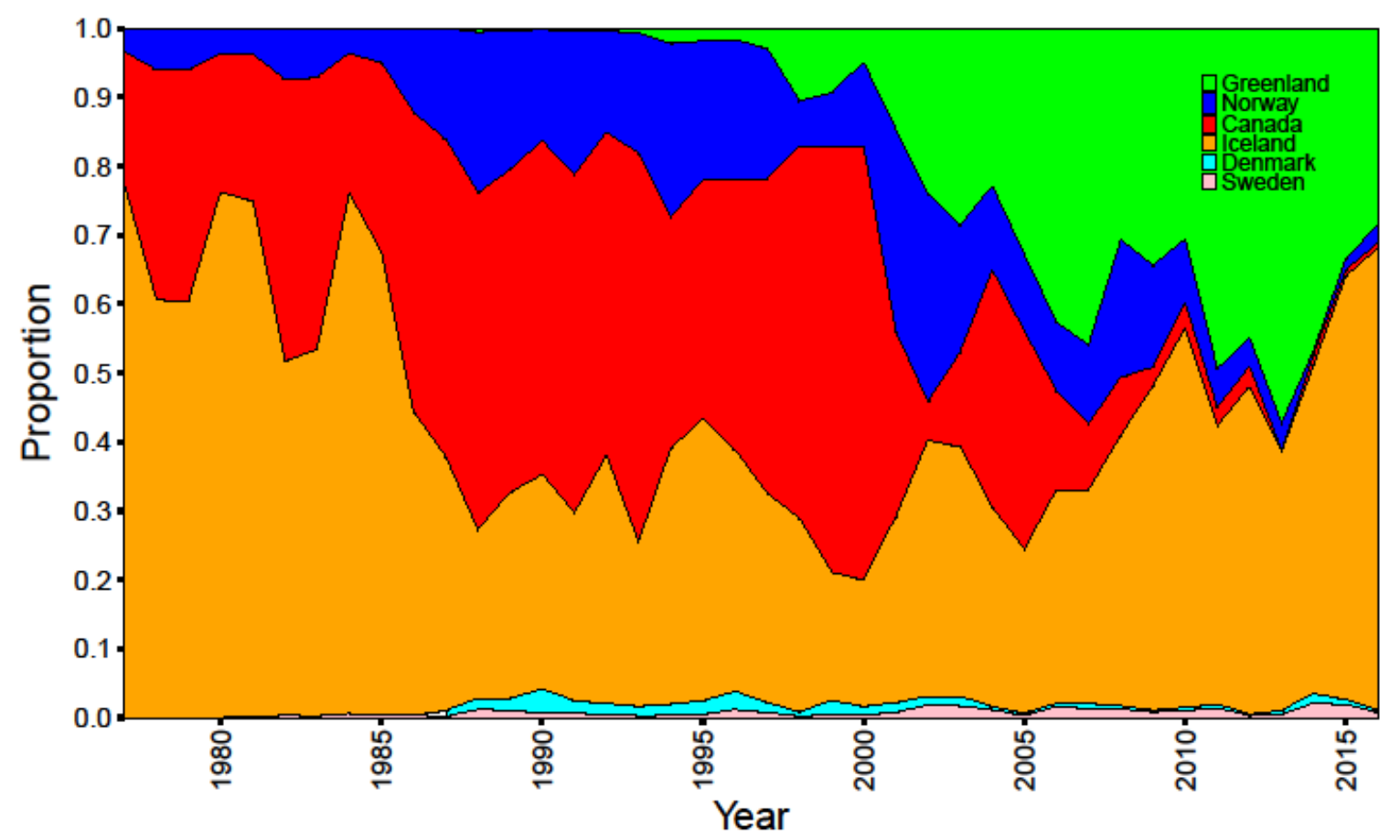

Figure 3. Proportion of landings of lumpfish roe landed by country between 1976 and 2016 . 

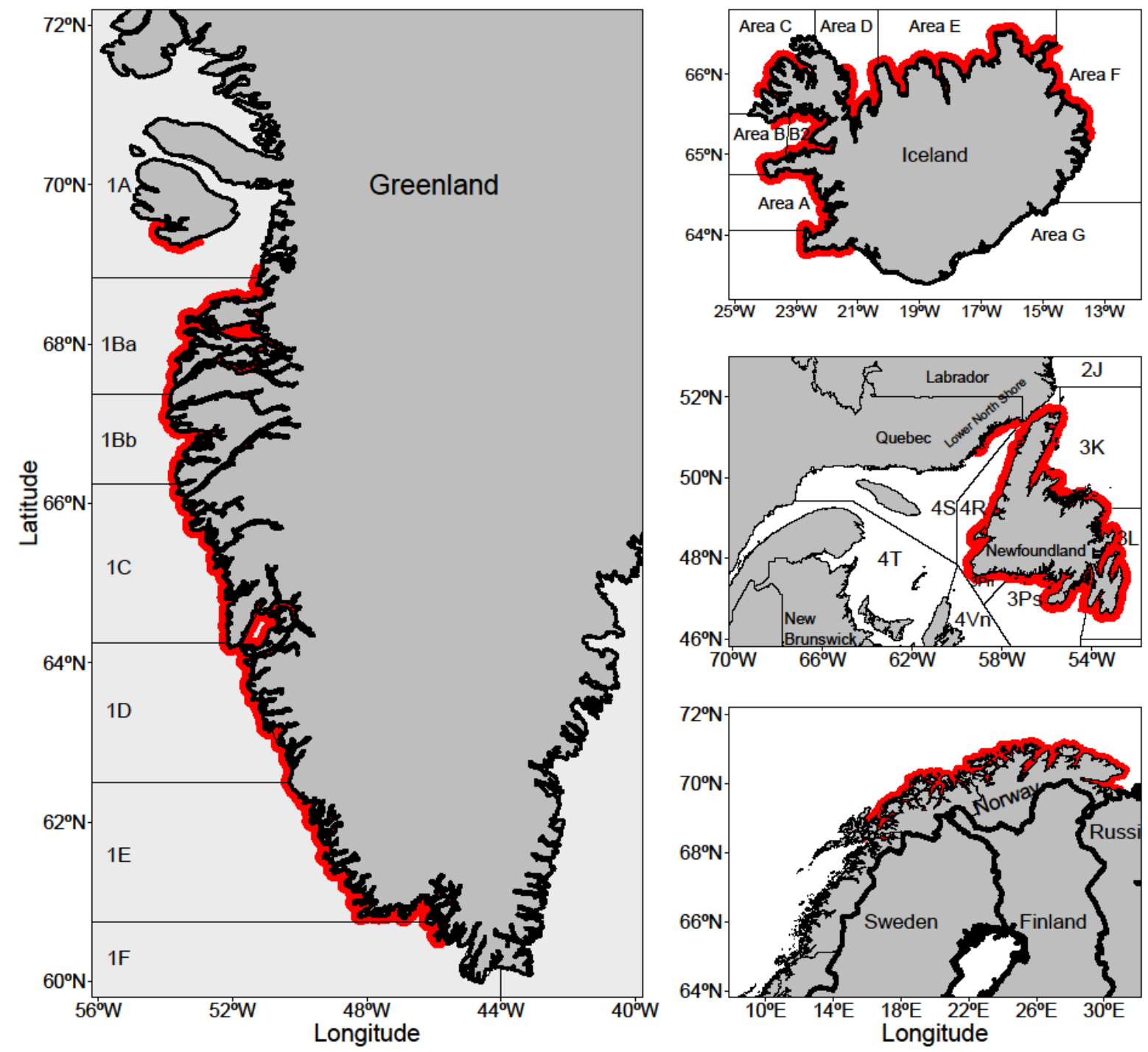

Figure 4. Map of Greenland, Iceland, Norway and Canada depicting the main fishing areas (red) for lumpfish. Lumpfish management areas are shown on Iceland map and NAFO statistical areas are shown on map of Greenland and Canada. 

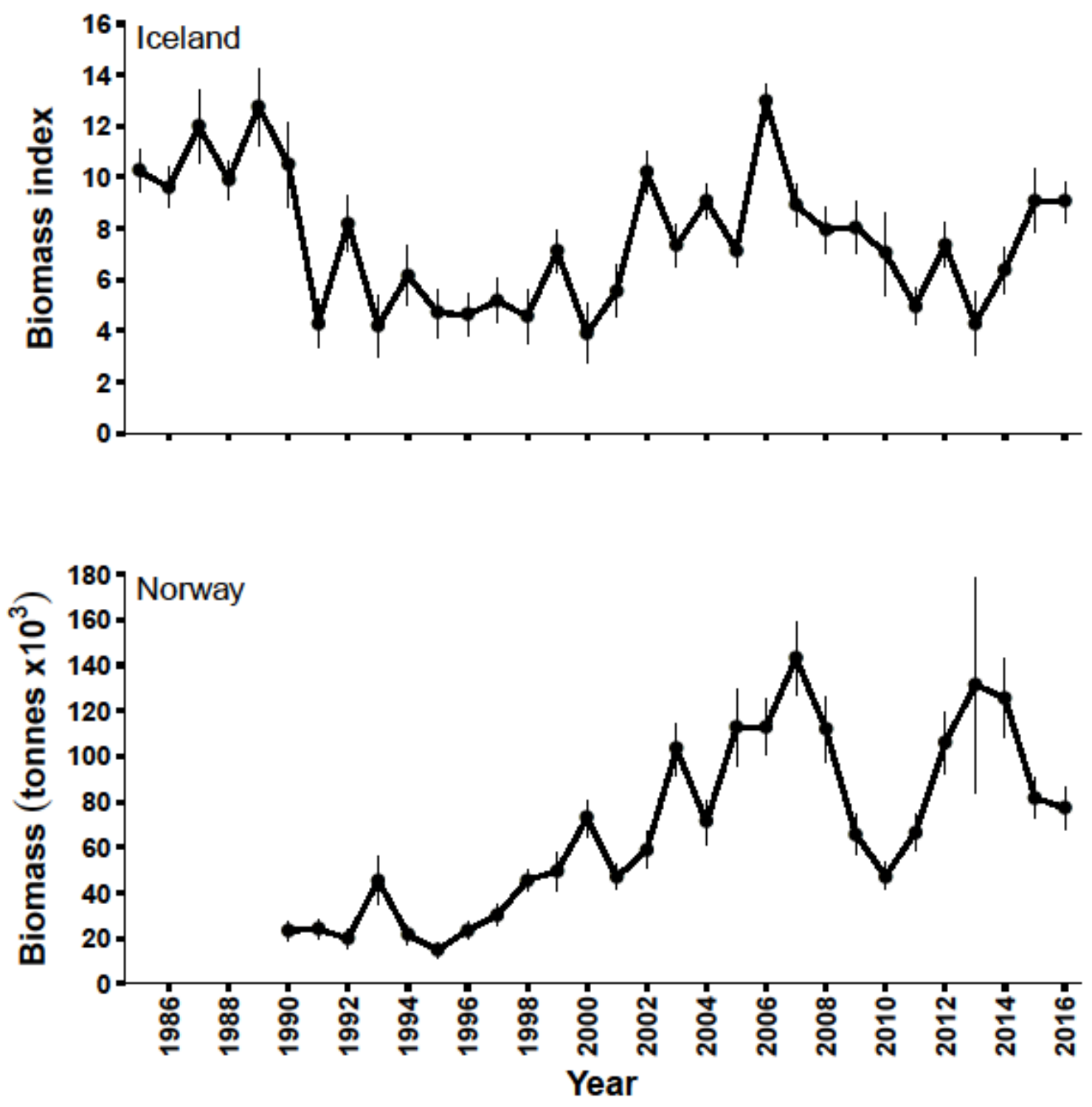

Figure 5. Biomass for index female lumpfish in Iceland from the Iceland spring groundfish survey and Norwegian 0 -group pelagic survey. $95 \%$ confidence intervals shown. 

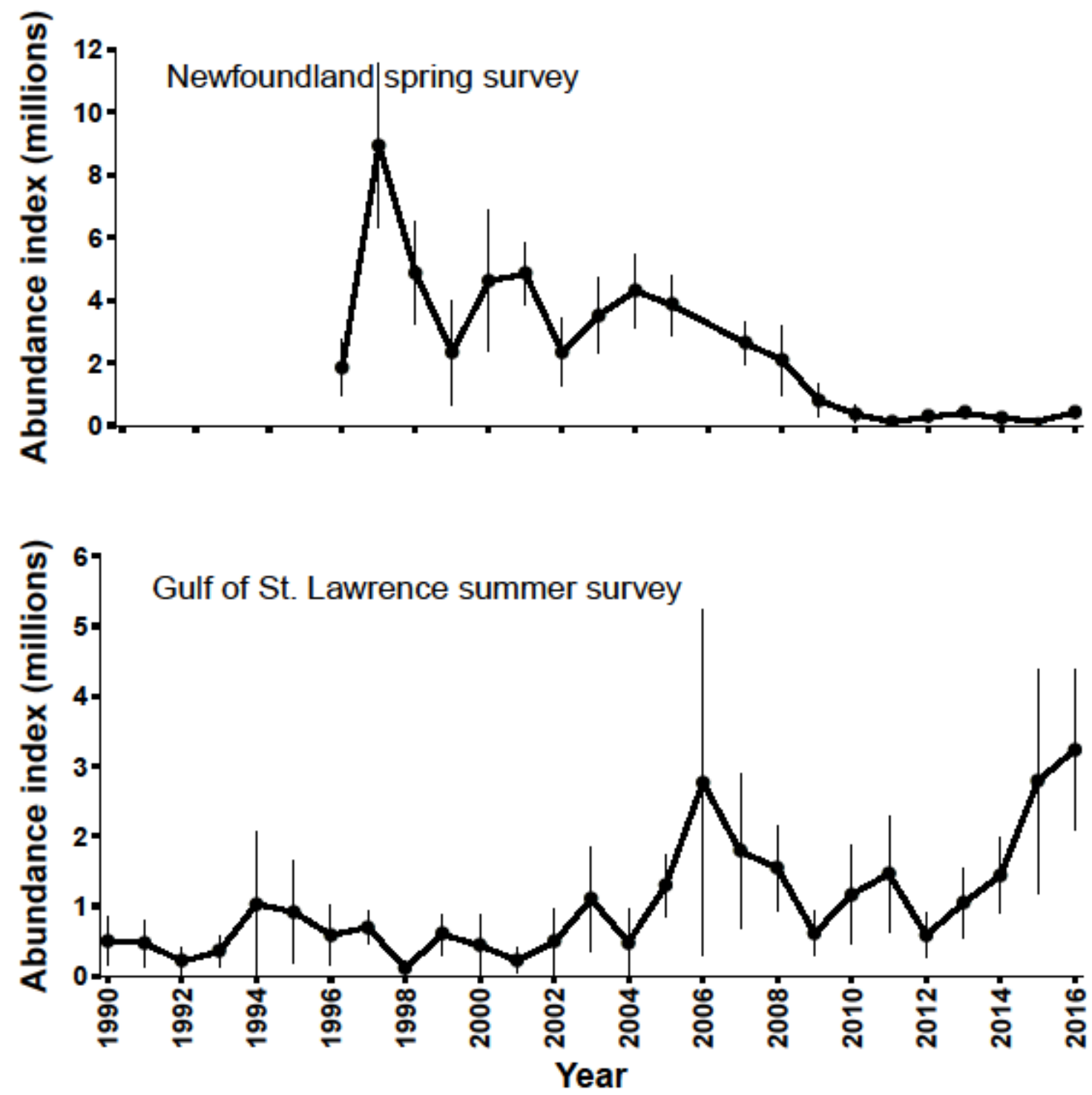

Figure 6. Abundance index from the spring and autumn bottom trawl survey in Northwest Atlantic Fisheries Organization (NAFO) Divisions 3LNOP and 2GHJ3KLNO respectively. 

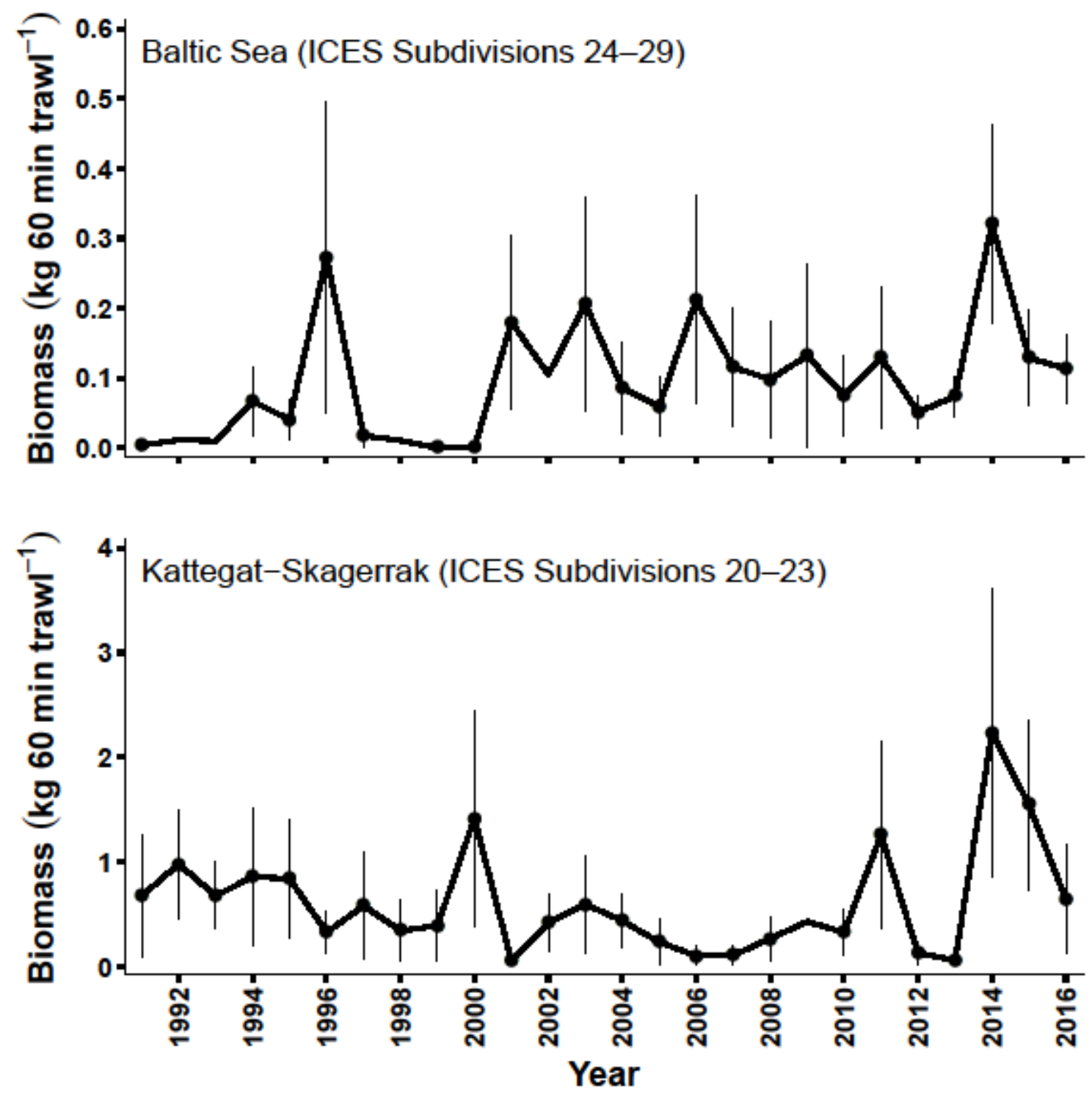

Figure 7. Average catch of lumpfish from the North Sea International Bottom Trawl Survey (IBTS) and Baltic Sea bottom trawl survey (BITS) standardized to 60 minute trawl. 


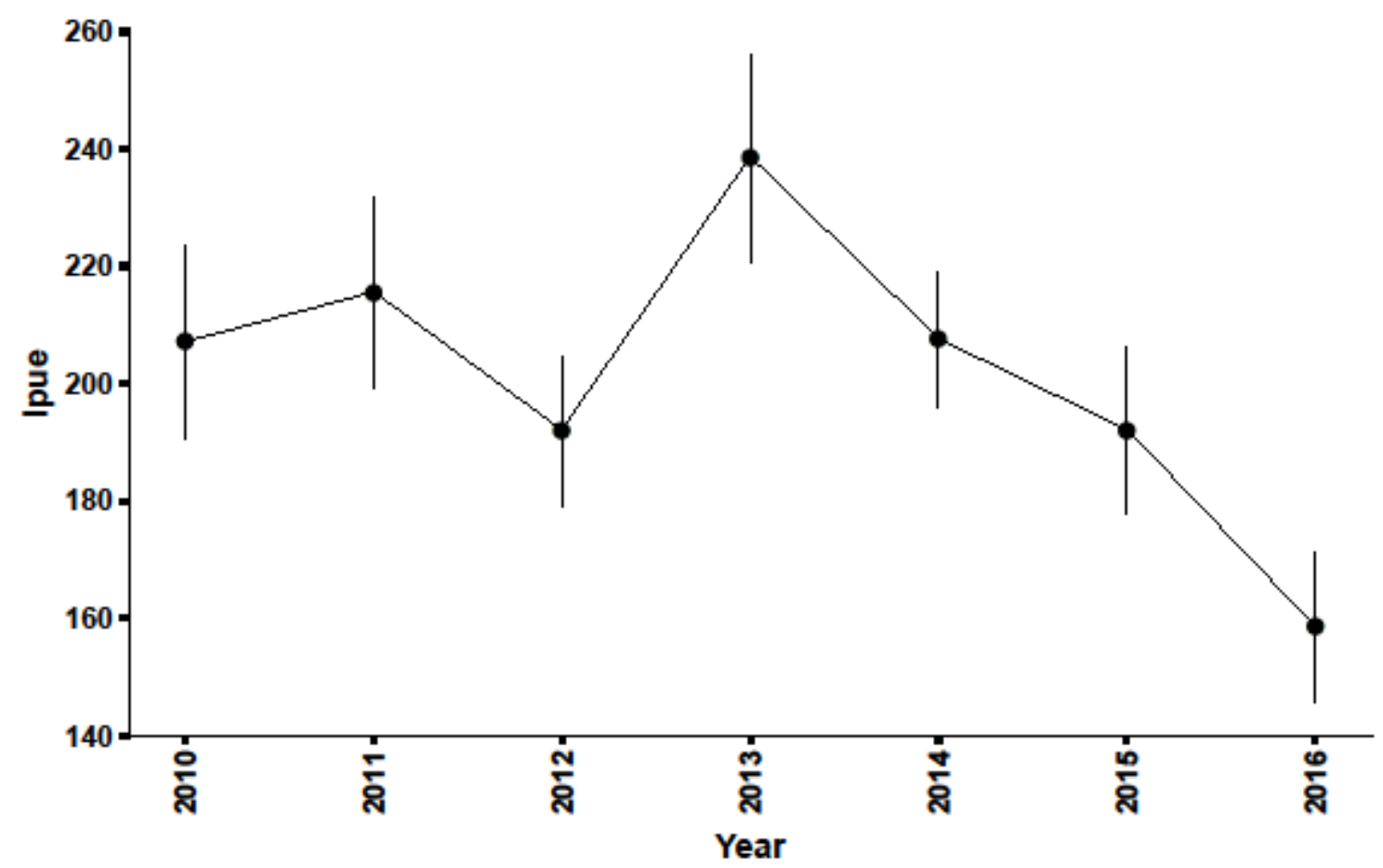

Figure. 8. Landings per unit effort (LPUE) from the Greenland lumpfish fishery. 


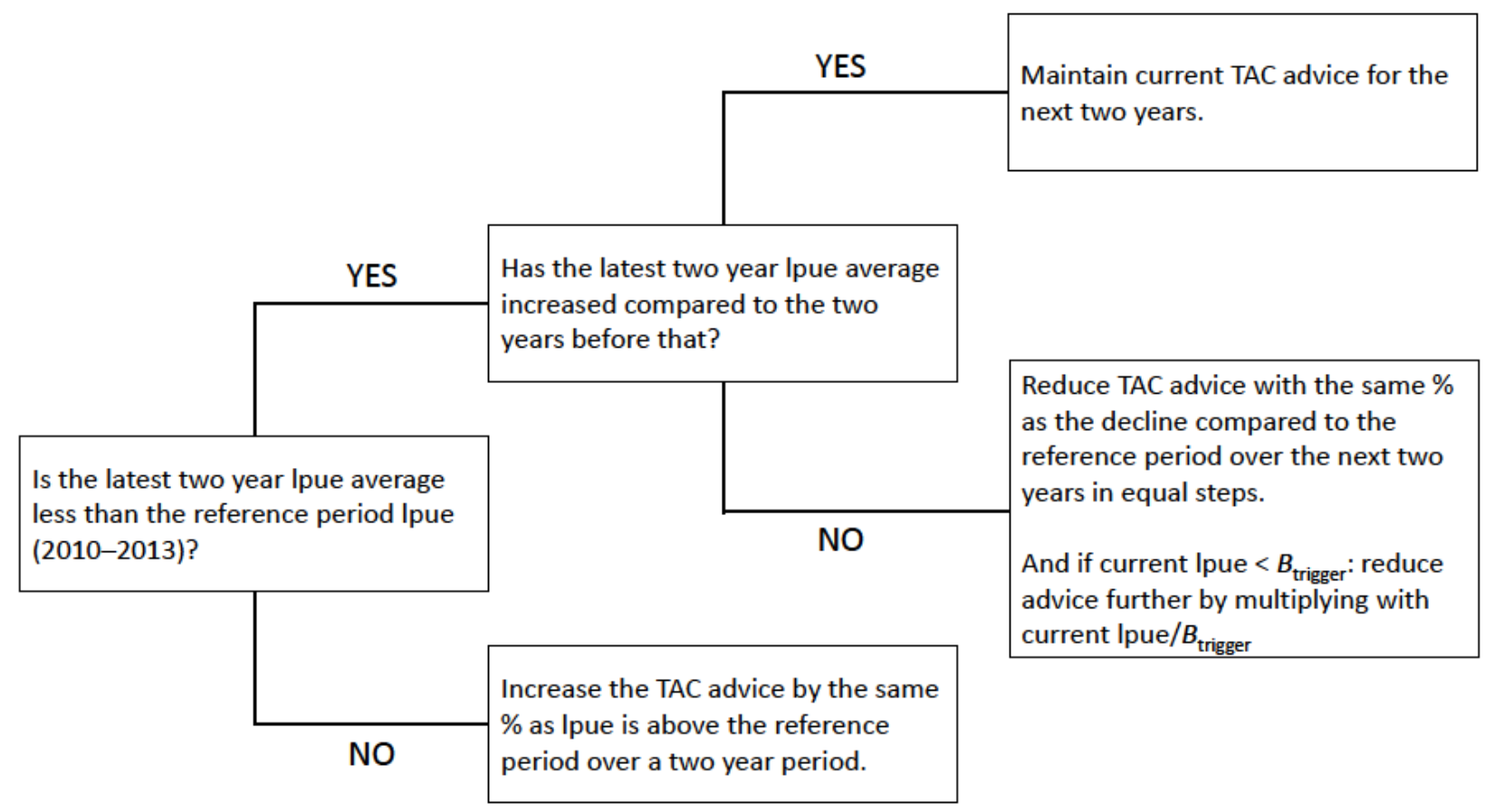

Figure 9. Harvest control rule for setting the total allowable catch and number of fishing days for the Greenland lumpfish fishery. 